\title{
Entities of Legal Policy
}

\author{
Timur Giorgievich Okriashvilii ${ }^{1}$, Albert Valentinovich Pavlyuk ${ }^{2}$, Natalya Igorevna Platonova ${ }^{3}$ \& Albert \\ Gumarovich Yakupov ${ }^{4}$
}

${ }^{1} \mathrm{PhD}$ in jurisprudence, Associate professor at the Department of Theory and History of State and Law, Kazan Federal University, aud. 305a, 18 Kremlyovskaya St. Kazan, 420008, Russia

${ }^{2} \mathrm{PhD}$ in jurisprudence, Deputy Head of the Department of Public Administration, Associate Professor, Moscow State Institute of International Relations (MGIMO), Aud. 3176, 76 Prospect Vernadskogo, Moscow, 119454, Russia

${ }^{3}$ Phd in Law, Associate Professor with the Department of Legal Foundations of Governance, MGIMO (University) under the MFA of Russia, School of Governance and Politics, Aud. 3176, 76 Prospect Vernadskogo, Moscow, 119454, Russia

${ }^{4}$ Bachelor of law, graduate the Department of Civil and Business law, Kazan Innovative University, Department of Civil and Business law, 71 M. Gafuri str., Kazan, 420108, Russia

Correspondence: Timur Giorgievich Okriashvili, $\mathrm{PhD}$ in jurisprudence, Associate professor at the Department of Theory and History of State and Law, Kazan Federal University, aud. 305a, 18 Kremlyovskaya St. Kazan, 420008, Russia. E-mail: okriashvili@yandex.ru

Received: June 9, 2019

doi:10.5539/jpl.v12n5p67
Accepted: August 25, $2019 \quad$ Online Published: August 31, 2019

URL: https://doi.org/10.5539/jpl.v12n5p67

\begin{abstract}
Legal policy is a transformation of political goals into state programs and projects and achievement of such goals based on law. Nowadays the problem of effectiveness of legal policy is extremely discussable.

We should underline that for the role of law in Russian society increases as well as a flow of legal information. Various legal acts have been adopted and the new system of legal regulation in different spheres (in particular, in politic sphere) is emerging. As the result our society, individuals and legal entities have more actively began using «Law» to solve their problems, to protect their rights, to resolve conflicts.

But narrow-minded and weak legal policy with the inappropriate legislation is continuously being reflected in the unsatisfactory implementation of social, economy and etc. policies. So, the effectiveness of legal policy determines, inter alia, how effective are the legal policy entities. Some of them take part in all forms of legal policy realization, some of them are active only in particular form. This research helps to understand the peculiarities of the role of legal policy entities.
\end{abstract}

Keywords: legal policy, principles of legal policy, entities of legal policy, NGO, president, parliament, courts

\section{Introduction}

The definition of legal policy is increasingly used in the scientific community, but still there is no a unique approach to its understanding. Legal policy may be deemed as a type of state policy, as a combination of legal methods and means to regulate social relations. But it is rather narrow as it stipulates neither legal policy entities nor the objects of legal policy. That is why we consider that more propriate definition is as follows: «legal policy is deemed as the activity of the state and municipal bodies, legal entities and individuals to ensure the functioning of the legal mechanism to realize the rights, freedoms and legitimate interests of individuals, society and state». Subject to official acts such as for example concept of national security, national projects, the principle objects of Russian legal policy are to protect national security, human rights and legal interests, as well as to fight against crime and corruption. To be effective in realization these aims the legal policy shall be based on the principles of the constitution and generally accepted norms of international law.

Legal Policy is required to form a full-fledged and effective legal system of the country and its regions. Today, with regard to, the ongoing politico-legal transformations in Russia development of scientifically based and effective legal policy becomes a priority in modern legal science and practice. The legitimate nature of such reforms depends on how success these problems are solved. 
Taking into consideration said above we should underline the several forms of the state legal policy's realization:

1) Lawmaking. The aims of this form are to create appropriate legal bases where all legal acts constitute the unique system, don't contradict each other.

2) Law enforcement. This form translated into by-laws acts and other individualized acts.

3) Law interpretation form translates into act of law interpretation both official and doctrinal. The Constitutional Court and Charter Courts of the regions play a special role, but they are not the exclusive actors as other legal policy entities may interpret legal norms.

4) Doctrinal form gives the scientific base for legal policy, elaborate the concepts and doctrines in different spheres.

5) Educational forms is required to give the professional lawyers who may act creatively and constructively in modern reality.

\section{Methods}

The authors used traditional scientific methods used to create a scientific product such as analysis, synthesis, analogy, generalization and comparison the formal legal legislation and the formal logical rationale, and others. The system method has helped to overview the role of the legal policy entities and the peculiarities of their legal status. In particular, the authors focused the non-for-profit organizations and their implementation if legal policy.

\section{Summary}

In the formation and implementation of legal policy all actors of political and legal life are involved: from public authorities to individuals. A special role among them is given to law-making and law enforcement authorities, which, forming and implementing the main directions of legal policy, create legal regulations and implement it when the parties of legal relations are unable to solve their conflict by their own.

From the above definition it follows that the main entity of legal policy is the state, represented by relevant public authorities stipulated in the states' Constitutions. For example, in the Russian Federation, the President, Parliament, Government and Court are such authorities. They are entitled to initiate legislation and give the official law interpretation. The President defines the general principles and aims of the state's development by means of annual Massage of the President. In accordance with the presidential act the Government has elaborated the national projects which may be deemed as a program acts of the legal policy.

So legal policy is based on law and is implemented by means of law. In general, Russian legislation compliance with the most international requirements and standards but we could hardly say that Russia is a legal state where the rule of law prevails. The level of implementation of legal norms is still rather low. The matter is that sometimes legal acts contradict each other, in some spheres we meet the overregulation. And of course there is a grate problem of low level of the consciousness of law that true liberty demands.

The researchers used to pay attention to public authorities and its role in legal policy. However, local governments and civil society institutions are worth to be mentioned. This article proposes to address the issue of the role of public associations in the formation and implementation of legal policy. Such entities attempt to shape legal policy through education, mobilization of interest group and others.

The reason for selecting subjects for research is not accidental, the participation of public associations provides a balance between state and public interests. They provide channels of communication between those who provide justice and their community; it also serves as a means of providing civic and legal training and of prevention. Moreover, their activities are of great importance for the development of civil society and the rule of law.

Subject to Art. 5 of the special Federal Law public associations are a voluntary, self-governing, non-commercial legal entity. It is incorporated by the individuals to achieve the social oriented goals. All public associations are non-for-profit organizations, and, therefore, are not intended to systematically obtain profits.

To implement their statutory goals, public associations have the right to incorporate their own media. Which, in the modern world, among the Internet, are platforms for the expression of public opinion, as well as the main tools for its formation.

Public associations use various technologies to bring information to the general public, including technologies for manipulating consciousness. However, the use of the latter does not contribute to the development of democracy, but quite the opposite. And only the informatization of society, which is understood as disclosing information, providing open access to it, conducting public education events, can be considered as a truly democratic strategy for the formation of public opinion. 
The Law «On Public Associations» gives the right to such legal entities to communicate to the general public information about the goals of creating a public association and its results. Such information can be considered as the basis of the information activity of public associations, allows to bring information to the general public regarding the activities of associations, to create a «certain image». At the same time, it seems that the activity of a public association should be as transparent as possible.

Considering the above, as well as the fact that the legal policy is implemented not only through law, but also through explanatory, ideological, organizational and other means, it can be stated that public associations have a powerful resource for its implementation.

Public associations also have the right to participate in the development of decisions of state authorities and local governments, through public monitoring, public discussion, as well as participate in public control in other forms. According to the results of public control, public organizations were granted the right to submit proposals and recommendations to state bodies and local governments on improving their activities and eliminating the causes of human rights violations. At the same time, the Federal Law «On the Basics of Public Control in the Russian Federation» establishes the obligation of these bodies to consider the final document based on the results of public control. Through the institution of public in the development of decisions of public authorities and local authorities, through public monitoring, public discussion, as well as participate in the conduct of public control in other forms. According to the results of public control, public organizations were granted the right to submit proposals and recommendations to state bodies and local governments on improving their activities and eliminating the causes of human rights violations. At the same time, the Federal Law «On the Basics of Public Control in the Russian Federation» establishes the obligation of these bodies to consider the final document based on the results of public control. Through the institution of public control, public associations participate directly in the formation, adjustment and implementation of legal policy.

The right to represent and protect the interests of citizens in state bodies and local self-government bodies is inextricably linked with the rights considered. Various forms of public control and others can also be called methods for its implementation. Public organizations often explain the mechanisms of implementation and protection of the rights of citizens, conduct statistical research, various events, rallies. Taking into considiration the publicity of their activities, it is also possible to talk about the existence of a passive influence on the formation and implementation of the state legal policy. After all, the legal policy is implemented not only through law, but also through explanatory, ideological, organizational and other means.

In this regard, it can be stated that public associations have a powerful resource for its implementation. Access to the media, the possibility of creating your own is the basis for the implementation of legal and ideological education of citizens, the formation of public opinion on certain social and political issues. Today, however, the activities of these associations are often «decorative».

Political parties have a special place among public associations, as they are granted the exclusive right to participate in elections, to nominate their candidates to participate in elections to legislative bodies of state power, as well as local governments. Nevertheless, it is obvious that the formation of public opinion, the expression of the opinions of citizens and the protection of their interests in the bodies of state power and local self-government are a necessary foundation for successful participation in elections.

The parties that enjoy the greatest support from voters on the election results are represented in the State Duma of the Russian Federation, as well as in the legislative bodies of the constituent entities. Thus, they are directly involved in the formation of the country's legal policy.

However, it is worth noting that until 2012 there were only 7 parties in Russia. The subsequent reform of the liberalization of legislation in the area of requirements for the creation and activities of political parties led to a rapid increase in their number, and today there are over 70 . However, these changes did not lead to the desired result - the development of a real multi-party system. If we turn to the consolidated financial reports of political parties, we can conclude that more than half of them exist «on paper». Moreover, often after «coming to power» political parties distance themselves from other institutions of civil society and are transformed into the structure of the state.

\section{Conclusions}

The reason for the existing problems of the development of public associations as an entity of legal policy lies in the peculiarities of the interaction of the state with public associations established in Russian society. On the one hand, the state is interested in the existence of public associations, a developed civil society, and broad involvement of the population. The state provides support to public associations, including financial ones, it is 
emphasized that joint activities in solving socially significant problems. It points out the need to develop mechanisms for public control over the implementation of legislation by authorized bodies, an increase in their role in the lawmaking and lawmaking process, as one of the forms of implementation of legal policy. Some authors even propose amendments to the legislation of the Russian Federation in order to endow public associations with legislative initiative, for example, subject to broad support from the public of various initiatives.

On the other hand, some decisions of public authorities are often the object of criticism from public associations, which causes discontent and the desire to reorient the efforts of such associations to solve other pressing problems.

However, the effective legal policy requires the cooperation of the State and the civil society. Any proposals to legislate should also be made open to extensive and comprehensive consultation within the community. Moral suasion, public scrutiny or civil society mobilization can often put sufficient pressure on the decision-making authorities in a society to take appropriate political decisions, to adopt the required laws and make the necessary amendments to the existed laws in in order to reach the national interests.

\section{Acknowledgements}

The work is performed according to the Russian Government Program of Competitive Growth of Kazan Federal University.

\section{References}

Fedorina, E. A. (2016). The priorities of the development of the legal policy of the Russian Federation. Leningradskiy uridicheski jurnal, (1), 78-83.

Gorshunov, D. N., \& Okriashvili, T. G. (2016). Private law principles in social processes: problem statement. Academy of Marketing Studies Journal, 20(1), 33-38.

Karasev, D. V. (2012). Forms of public participation in the law-making process in Russia. Bulletin of Samara State University, 8(1), 247-252.

Malakhov, V., \& Avtonomov, A. (Eds.). (2018). Civil Society: textbook. Noscow: MGIMO.

Merculov, S. S. (2015). The interaction of civil society with the state authorities of the Russian Federation: problematic aspects. Bulletin of state and municipal governance, 22-27. https://doi.org/10.12737/17870

Okriashvili, T. G., \& Yakupov, A. G. (n.d.). Methodology the Concept of the Unity of the Category of Claim in the Material and Procedural Sense. Revista Publicando, 4(13), 578-584.

Okriashvili, T. G., Gurinovich, A. G., Pavlyuk, A. V., \& Yakupov, A. G. (2018). About the need to eliminate violations of the constitutional principle on equality of the legislative, executive and judicial branches of government in terms of remuneration and pensions paid to civil servants from office of the supreme state power bodies of the Russian Federation. Dilemas contemporáneos: Educación, Política y Valores, 6(1), 20.

Vesnin, A. V. (2016). Public Opinion Technologies. The power, (6), 70-74.

Voronin, M. V. (2015). Consistency in law: theoretical model and practical significance. Research Journal of Applied Sciences, 10(12), 851-856.

Voronin, M. V., \& Zakharova, M. V. (2017). The problem of the exercise of law in russia and france: national and international aspects. Quid: Investigación, Ciencia y Tecnología, (1), 1642-1646.

\section{Copyrights}

Copyright for this article is retained by the author(s), with first publication rights granted to the journal.

This is an open-access article distributed under the terms and conditions of the Creative Commons Attribution license (http://creativecommons.org/licenses/by/4.0/). 